\title{
KESALAHAN PENULISAN PADA PAMFLET DAN \\ PAPAN NAMA PERTOKOAN \\ DI KOTA MEDAN
}

\author{
Warniatul Ulfah \\ 8156191019 \\ Pendidikan Bahasa dan Sastra Indonesia
}

\begin{abstract}
Abstrak
Kajian ini bertujuan untuk menggambarkan kesalahan bahasa dalam penulisan pamflet dan papan nama pertokoan. Sampel di ambil di wilayah medan dengan 3 sampel untuk pamflet dan 3 sampel untuk papan nama pertokoan. Tulisan ini merupakan studi deskriptif yang difokuskan pada penggalian data-data kualitatif, dengan harapan akan diperoleh gambaran lebih detail dan rinci terhadap objek penelitian. Dari hasil kajian ini, secara umum dapat dikatakan bahwa kesalahan berbahasa Indonesia pada penulisan pamflet dan papan nama pertokoan masih sering dijumpai yang belum sesuai dengan kaidah bahasa Indonesia yang baik dan benar. Bentuk-bentuk kesalahan penulisan meliputi kesalahan penulisan tanda baca, singkatan, pemilihan kata, ejaan dan makna yang disampaikan belum jelas. Kesalahan penulisan pada pamflet dan papan nama pertokoan diakibatkan oleh pengaruh penggunaan bahasa sehari-hari atau tulisan yang ditulis berdasarkan ucapan lisan masyarakat, keterbatasan pengetahuan mengenai aturan bahasa Indonesia, serta adanya kecenderungan sekadar meniru. Selain itu, masyarakat juga kurang menghiraukan bagaimana penggunaan bahasa dalam tulisan yang benar, sehingga kesalahan tersebut berpotensi memicu persoalan problematika kesalahan bahasa dalam penulisan pamflet dan papan nama pertokoan.
\end{abstract}

Kata kunci: kesalahan bahasa, penulisan pamflet dan papan nama pertokoan

\section{PENDAHULUAN}

Masalah kesalahan berbahasa
dalam menerapkan kaidah bahasa

Indonesia yang baik dan benar merupakan "problem wajar" yang hampir terjadi pada setiap pemakai bahasa. Orang bisa saja melakukan sebuah kesalahan atau "terpeleset" dari kaidah walaupun sebenarnya sudah berusaha menerapkan kaidah bahasa tersebut dengan sebaik dan sebenar mungkin. Masalah tersebut tidak hanya menimpa orang-orang yang dianggap awam atau kurang mampu berbahasa, mereka yang dianggap mahir juga sangat mungkin mengalaminya. Hal ini disebabkan karena ketidak berlakuan hukum yang mutlak bagi pengguna bahasa yang salah, seandainya hal tersebut diberlakukan, pasti banyak para terpidana yang masuk ke dalam penjara akibat salah menggunakan bahasa baik secara lisan maupun tulisan.

Kehidupan masyarakat yang majemuk menimbulkan sebuah perilaku 
yang berbeda, sehingga menciptakan sebuah proses komunikasi yang beragam. Proses komunikasi inilah yang dinamakan tindak ujar atau tindak tutur. Tindak ujar atau tindak tutur adalah kajian tuturan berdasarkan makna atau arti tindakan dalam tuturannya (Chaer dan Agustina, 2004: 65). Dalam hubungan dengan kehidupan masyarakat, bahasa Indonesia telah terjadi pelbagai perubahan. Terutama yang berkaitan dengan tatanan baru kehidupan dunia dan perkembangan ilmu pengetahuan serta teknologi, khususnya teknologi informasi yang semakin sarat dengan tuntutan dan tantangan globalisasi. Kondisi itu telah menempatkan bahasa Asing terutama bahasa Inggris pada posisi strategis yang memungkinkan bahasa itu memasuki berbagai sendi kehidupan bangsa dan mempengaruhi perkembangan bahasa Indonesia.

Penggunaan bahasa asing dan bahasa daerah tersebut telah mempengaruhi cara pikir masyarakat Indonesia dalam berbahasa Indonesia resmi. Kondisi itulah yang menyebabkan terjadinya kesalahan berbahasa Indonesia. Untuk itu, diperlukan tata cara penggunaan bahasa Indonesia yang baik dan benar. Atas dasar tersebut, peneliti ingin memberikan pengetahuan tentang perkembangan Bahasa Indonesia dalam fenomena pemilihan diksi yang tepat dalam proses komunikasi, baik secara lisan maupun dalam tulisan.
Penelitian ini dimaksudkan untuk menganalisis kesalahan berbahasa Indonesia pada penulisan pamflet dan papan nama pertokoan. Pamflet merupakan salah satu dari media publisitas yang ditujukan pada masyarakat. Pamflet adalah tulisan yang dapat disertai dengan gambar atau tidak, tanpa penyampulan maupun penjilidan, yang dicantumkan pada selembar kertas di satu sisi atau kedua sisinya, lalu dilipat atau dipotong setengah, sepertiga, atau bahkan seperempatnya, sehingga terlihat lebih kecil (dapat juga disebut selebaran). Papan nama pertokoan adalah elemen yang harus didahulukan keberadaanya sebelum perlengkapan kantor yang lain. Karena dengan papan nama orang lain menjadi lebih mengetahui dimana lokasi kantor kita, pada papan nama pertokoan terdapat identitas, penunjuk dan adversiting. Sering ditemukan kesalahan penulisan pada papan nama pertokoan dan pamflet. Untuk itu, peneliti tergerak untuk melakukan penelitian atas pelbagai kesalahan penulisan yang tidak sesuai dengan kaidah baku bahasa Indonesia pada media luar ruang tersebut. Dalam penelitian ini diambil tiga sampel untuk pamflet dan 3 sampel papan nama pertokoan.

Pada dasarnya kesalahan berbahasa yang terjadi di masyarakat merupakan sebuah kebiasaan yang sudah melekat turun-temurun hingga sulit untuk 
dilepaskan. Selain itu, bahasa sehari-hari lebih mudah dilafalkan dan kurangnya wawasan masyarakat tentang bagaimana bahasa Indonesia yang baik dan benar. Dengan demikan terjadilah penulisanpenulisan yang tidak sesuai dengan kaidah bahasa Indonesia yang baik dan benar.

Berdasarkan uraian di atas, dalam penelitian ini dapat dirumuskan permasalahan sebagai berikut.

1. Bagaimanakah bentuk kesalahan berbahasa Indonesia pada penulisan pamflet dan papan nama pertokoan?

2. Bagaimana hasil analisis terhadap bentuk-bentuk kesalahan berbahasa Indonesia pada penulisan pamflet dan papan nama pertokoan?

Penelitian ini bertujuan sebagai berikut

1. Untuk mengetahui bentuk-bentuk kesalahan berbahasa Indonesia pada penulisan pamflet dan papan nama pertokoan

2. Untuk megetahui hasil analisis bentuk-bentuk kesalahan berbahasa Indonesia pada penulisan pamflet dan papan nama pertokoan.

\section{METODE PENELITIAN}

Penelitian ini menggunakan metode deskriptif. Penggunaan metode tersebut untuk memperoleh deskripsi secara faktual mengenai hal-hal yang akan di teliti yang sedang berlangsung pada masa sekarang. Penelitian yang dilakukan semata-mata hanya berdasarkan fakta yang ada atau fenomena yang ada sehingga yang dihasilkan atau dicatat berupa perincian seperti potret paparan sebagaimana adanya (Sudaryanto 1988:62).

\section{a. Teknik Pengumpulan Data}

Pengumpulan data penelitian ini menggunakan teknik observasi dan teknik catat atau rekam (Mahsun, 2005). Teknik ini dilakukan untuk memperoleh data secara langsung dari objek penelitian. Pengamatan dilakukan pada pamflet dan papan nama pertokoan yang terdapat di lokasi penelitian. Data kesalahan penulisan bahasa pada media tersebut teramati dicatat atau direkam sebagai korpus data.

\section{b. Teknik Penganalisisan Data}

Data yang sudah terkumpul atau data teridentifikasi dicatat dalam korpus data. Selanjutnya, data tersebut diklasifikasikan dan dianalisis berdasarkan aspek dan tipe kesalahan. Sesuai dengan karakteristikdata yang ingin diperoleh, penganalisisan data penelitian ini menggunakan teknik kualitatif. Hal ini sesuai dengan karakteristik data yang akan dideskripsikan (Mahsun, 2005). Berkaitan dengan ini, Ellis (dalam Tarigan, 2011: 68) mengemukakan bahwa langkah kerja analisis kesalahan berbahasa adalah mengumpulkan data, mengidentifikasikan data, menjelaskan kessalahan, dan mengevaluasikan. 


\section{PEMBAHASAN HASIL PENELITIAN}

\section{A. Analisis Penulisan Pada Pamflet}

Peneliti mengambil tiga sampel pamflet yang akan diteliti, berikut pembahasannya

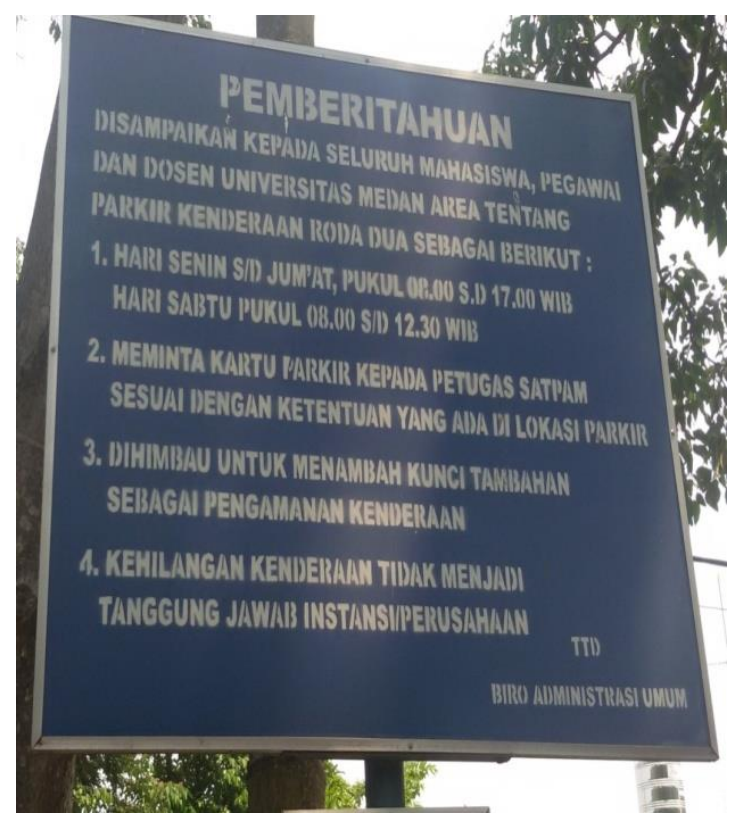

\section{Gambar 1}

Gambar 1 di ambil pada parkiran Universitas Medan Area tanggal 29 Agustus 2015. Pada pamflet tersebut ditemukan beberapa kesalahan yang akan dibahas, berikut ini pembahasannya.

Kesalahan yang ditemukan pada pamflet di atas.

1. Kesalahan yang ditemukan pada pernyataan kalimat pembuka yaitu pada penggunaan kata disampaikan, kenderaan dan tanda baca titik dua (:).

2. Penulisan pada kalimat nomor 1 ditemukan beberapa kesalahan yaitu makna kalimat yang belum jelas tentang informasi apa yang disampaikan, penggunaan kata hari dan jum'at, penggunaan tanda baca koma (,) dan penggunaan singkatan.

3. Penulisan pada kalimat nomor 3 ditemukan beberapa kesalahan yaitu penggunaan kata dihimbau, kunci tambahan dan kenderaan.

4. Pada kalimat nomor 4 kesalahan yang ditemukan yaitu pada kata kenderaan (tidak baku) yang seharusnya menjadi kendaraan (baku).

1. Pembahasan kesalahan nomor 1

a. Penggunaan kata Pemberitahuan dan Disampaikan

PEMBERITAHUAN

DISAMPAIKAN KEPADA SELURUH MAHASISWA, PEGAWAI DAN DOSEN UNIVERSITAS MEDAN AREA TENTANG PARKIR KENDERAAN RODA DUA SEBAGAI BERIKUT :

Kata Pemberitahuan terdiri dari awalan pem+ dan akhiran +an (pem+.....an) dengan dua kata dasar beri dan tahu, jika digabung menjadi beritahu yang bermakna menjadikan supaya tahu (mengerti). Setelah kata beritahu dibentuk dengan penghubung pem+ dan akhiran tan maka menjadi morfem terikat yaitu pemberitahuan yang bermakna pengumuman, maklumat, proses, cara serta perbuatan memberitahukan suatu informasi. Suatu informasi yang 
diberitahukan melaui tulisan hendaknya dapat dimengerti oleh setiap pembaca.

Penggunaan di pada kata disampaikan yang terletak pada awal kalimat tidak berfungsi sebagai kata depan, melainkan awalan, karena di sebagai kata depan sesuai dengan fungsinya, maka $d i$ merupakan kata tersendiri yang menunjukkan tempat, tujuan dan arah, penulisannya dipisahkan dari kata yang mengikutinya. Contoh: di rumah. Sedangkan Secara umum fungsi awalan $d i$ adalah pembentuk kata kerja pasif, penulisannya digabungkan dengan kata yang mengikutinya. Contoh: diterbitkan. Akhiran +kan pada kata disampaikan bermakna benefaktif. Dalam kamus Besar Bahasa Indoneisa (2007:132) benefaktif berarti bersangkutan dengan perbuatan (verba) yang dilakukan untuk orang lain. Kata disampaikan (di+sampai+kan) merupakan bentuk pasif dari menyampaikan yang artinya memberikan sesuatu pada yang dituju atau tiba pada yang dituju. Jika pada awal kata sudah ada kata pemberitahuan yang menjadi judul, maka kata disampaikan tidak perlu dituliskan lagi karena makna kata pemberitahuan sudah menjelaskan perbuatan memberitahukan suatu informasi yang sama juga pada makna kata disampaikan, artinya kedua kata tersebut sama-sama memberitahukan. Oleh karena itu, kata disampaikan sebaiknya tidak ditulis.

\section{b. Kata Kenderaan atau Kendaraan}

Penggunaan kata Kenderaan merupakan bahasa yang tidak baku. Kata kenderaan umumnya digunakan masyarakat pada bahasa lisan. Badudu (1986:22) menjelaskan "Gejala salah kaprah yang terjadi merupakan kesalahan yang menjadi umum, lumrah, biasa karena pemakaian bahasa yang salah itu menjadi tinggi frekuensinya, kekerapannya, sehingga kebanyakan pemakai bahasa tidak lagi sadar bahwa bentuk atau susunan yang digunakannya itu sebenarnya salah". Hal tersebut jelas terlihat dengan munculnya kata kenderaan yang berulang seperti pada kalimat nomor 3 dan nomor 4 yang ada pada pamflet tersebut. Penulisan kata kenderaan yang salah tertulis itu merupakan pengaplikasian bahasa lisan yang digunakan masyarakat sehari-hari atau bahasa lisan yang diubah ke dalam bentuk tulisan. Kata tersebut sering terdengar pada pelafalan yang diucapkan oleh masyarakat menjadi kendraan, secara tidak langsung bunyi huruf " $d$ " dari susunan huruf ke-4 yang didengar menjadi [de]. Pengucapan kata kenderaan tersebut terbentuk secara terus menerus di kalangan masyarakat, sehingga kata tersebut kurang dihiraukan lagi kebenaran maknanya, padahal kata kenderaan tidak memiliki 
makna jika dilihat dari Kamus Besar Bahasa Indonesia. Dalam Kamus Besar Bahasa Indonesia (2007:543) kendaraan adalah sesuatu yang digunakan untuk dikendarai atau dinaiki (seperti kuda, kereta, mobil). Oleh karena itu, penulisan yang benar adalah kendaraan.

\section{c. Penggunaan Tanda Baca Titik Dua} (:)

Menurut Ejaan Yang Disempurnakan (2012:41), Tanda titik dua dipakai pada akhir suatu pernyataan lengkap yang diikuti rangkaian atau pemerian. Selain itu, sebelum tanda baca titik dua (:) tidak dibenarkan menggunakan jarak atau spasi. Oleh karena itu pada akhir kata dari kalimat pernyataan pertama tidak diberi jarak sebelum menggunakan tanda baca titik dua (:),

Perbaikan kalimat pembuka menjadi:

"KEPADA SELURUH MAHASISWA, PEGAWAI DAN DOSEN UNIVERSITAS MEDAN AREA TENTANG PARKIR KENDARAAN RODA DUA SEBAGAI BERIKUT:".

2. Pembahasan kesalahan pada nomor 2

Penulisan kalimat pada nomor satu yaitu:

HARI SENIN S/D JUM'AT, PUKUL 08.00 S.D 17.00 WIB

HARI SABTU PUKUL 08.00 S/D 12.30 WIB

\section{a. Makna Kalimat Belum Jelas}

Kalimat diatas masih keliru, karena tidak dijelaskan apa yang dimaksud oleh keterangan hari dan waktu yang tertera pada pamflet tersebut. Seharusnya terdapat penjelasan mengenai aturan apa yang berlaku pada waktu yang disampaikan. Untuk memperjelas makna, pada awal kalimat ditambahkan kalimat aturan parkir belaku pada, penambahan 4 unsur kata tersebut memberikan makna yang jelas mengenai keseluruhan kalimat.

\section{b. Penggunaan kata Hari}

Menurut Kamus Umum Bahasa Indoneisa (2003:406) Hari adalah waktu dari pagi sampai pagi lagi (yaitu satu putaran bumi pada sumbunya, 24 jam). Sedangkan Senin dalam Kamus Besar Bahasa Indonesia (2007:1038) adalah nama hari ke-2 dalam jangka waktu 1 minggu. Dapat disimpulkan bahwa kata Senin sudah menunjukkan keterangan hari. Oleh karena itu, kata Hari pada nomor 1 tidak perlu dituliskan lagi.

\section{c. Kata Jum'at atau Jumat}

Kata Jum'at merupakan nama hari ke6 yang ada dalam seminggu, penulisan kata tersebut tidak memerlukan tanda baca koma (') setelah penulisan Jum. Berdasarkan Kamus Besar Bahasa Indonesia (2007:480) kata tersebut ditulis dengan kata Jum'at. Kata Jum'at pada pamflet tersebut ditulis berdasarkan lafal yang sering diucapkan masyarakat, bunyi 
pada ['at] yang keluar dari tenggorokan membacakan lafal hari dalam bahasa arab yaitu “Jumu'ati”.

\section{d. Penggunaa Tanda Baca Koma (,)}

Tanda baca koma (,) pada pamflet tersebut berfungsi untuk memisahkan keterangan waktu pada hari dan pukul. Jika itu yang dimaksud, seharusnya penulis pada pamflet tersebut konsisten dalam menggunakan tanda baca koma (,) karena keterangan waktu hari dan pukul terdapat pada dua bagian yaitu pada “SENIN S/D JUMAT, PUKUL 08.00 S.D 17.00 WIB" dan "SABTU PUKUL 08.00 S/D 12.30 WIB". Sehingga tanda baca koma (,) seharusnya dituliskan pada kedua bagian tersebut, begitu juga sebaliknya ketika pada keterangan waktu kedua tidak menggunakan tanda baca koma (,), keterangan waktu pada bagian pertama juga tidak menggunakan tanda baca koma (,). Peneliti menyarankan tidak perlu lagi menggunakan tanda baca koma (,) pada kedua bagian keterangan waktu tersebut.

\section{e. Penggunaan Singkatan "S/D"}

Singkatan adalah bentuk singkat yang terdiri atas satu huruf atau lebih. Aturan singkatan menurut Ejaan Yang isempurnakan pada gabungan kata yang terdiri atas dua huruf masing-masing diikuti tanda titik, yaitu:
a.n. (atas nama)
u.b. (untuk beliau)
u.p. (untuk perhatian)

Penyingkatan "S/D" tidak dibenarkan penggunakan garis miring (/), karena garis miring (/) berfungsi sebagai pengganti kata atau dan tiap. Contoh: dikirimkan lewat darat/laut. Oleh karena itu, penulisan yang benar adalah "s.d." (sampai dengan), selain itu untuk huruf "s" dan "d" tidak menggunakan huruf kapital.

Perbaikan kalimat nomor 1 menjadi:

ATURAN PARKIR BERLAKU PADA SENIN S.D. JUMAT PUKUL 08.00 S.D. 17.00 WIB DAN SABTU PUKUL 08.00 S.D. 12.30 WIB".

\section{Pembahasan Kesalahan pada Nomor 3}

Penulisan pada kalimat nomor 3 yaitu:

"DIHIMBAU UNTUK

\section{MENAMBAHKAN KUNCI}

TAMBAHAN SEBAGAI

\section{PENGAMANAN KENDERAAN"}

\section{a. Penggunaan kata Kunci Tambahan atau Gembok}

Penggunaan kata kunci tambahan masih keliru. Kata tersebut memiliki makna menggunakan kunci lebih dari satu, sedangkan yang dimaksud menggunakan gembok. Kunci merupakan alat yang terbuat dari logam yang berfungsi untuk membuka, menghidupkan atau mengancing pintu, besi, gembok, kendaraan dan sebagainya dengan cara memasukkannya ke dalam lubang yang ada pada induk kunci; anak kunci. 
Penggunaan kata kunci tambahan diganti dengan kata gembok. Karena kunci tambahan yang dimaksud sebagai alat untuk membuka gembok yang sama fungsinya dengan kunci yang berfungsi untuk menghidupkan atau menjalankan mesin kendaraan. Gembok merupakan induk kunci yang digunakan sebagai pengunci tambahan yang biasanya pada kendaraan roda dua dipasang di jari-jari ban. Oleh karena itu, penggunaan yang tepat adalah Gembok.

\section{b. Penggunaan Kata Dihimbau atau Diimbau}

Penulisan kata dihimbau tidak benar. Awalan di pada kata dihimbau yang terletak pada awal kalimat berfungsi sebagai awalan. Sedangkan jika diambil kata himbau, penulisan kata yang baku sesuai dengan Ejaan Yang Disempurnakan (2012:206) adalah Imbau yang bermakna seruan ajakan serius. Seharusnya imbaumengimbau yang artinya meminta (menyerukan) dengan sungguh-sungguh, mengajak, memanggil, menyebut nama orang. Oleh karena itu, penulisan kalimat nomor 3 menjadi:

"DIIMBAU UNTUK MENAMBAHKAN GEMBOK SEBAGAI PENGAMANAN KENDARAAN"

Setelah peneliti mengalisis, penulisan perbaikan pada pamflet tersebut yaitu:

\section{PEMBERITAHUAN}

KEPADA SELURUH MAHASISWA, PEGAWAI DAN DOSEN UNIVERSITAS MEDAN AREA TENTANG PARKIR KENDARAAN RODA DUA SEBAGAI BERIKUT:

1. ATURAN PARKIR BERLAKU PADA SENIN S.D. JUMAT PUKUL 08.00 S.D. 17.00 WIB DAN SABTU PUKUL 08.00 S.D. 12.30 WIB".

2. MEMINTA KARTU PARKIR PADA PETUGAS SATPAM SESUAI DENGAN KETENTUAN YANG ADA DI LOKASI PARKIR

3. DIIMBAU UNTUK MENAMBAHKAN GEMBOK SEBAGAI PENGAMANAN KENDARAAN

4. KEHILANGAN KENDERAAN TIDAK MENJADI TANGGUNG JAWAB INSTANSI/PERUSAHAAN

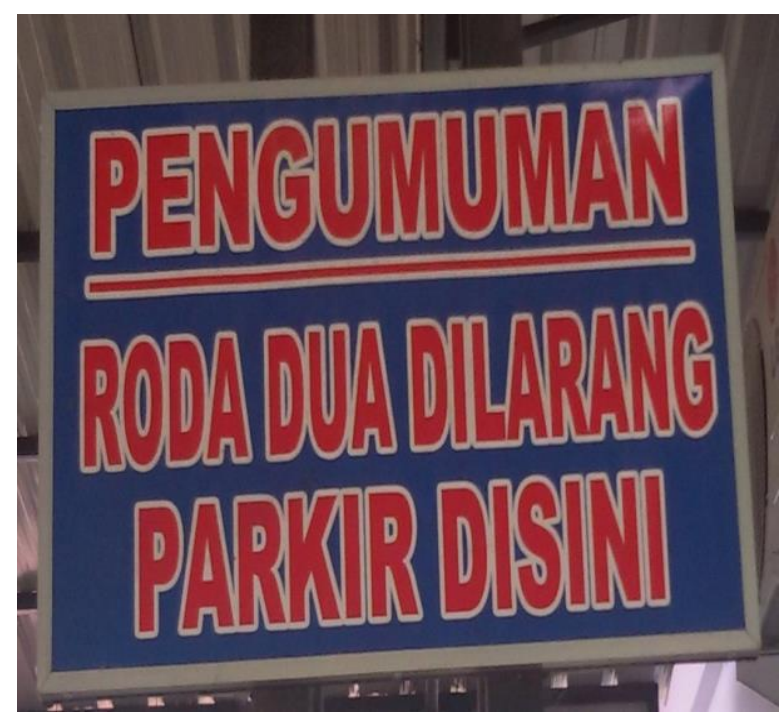

\section{Gambar 2}

Gambar 2 di atas yang di ambil pada parkiran Universitas Medan Area tanggal 29 Agustus 2015. Pada pamflet tersebut ditemukan beberapa kesalahan yang akan dibahas, berikut ini pembahasannya. 


\section{a. Kalimat Roda Dua Dilarang Parkir Disini}

Roda Dua terdiri dari dua unsur kata yaitu Roda dan Dua. Dalam Kamus Besar Bahasa Indonesia (2007: 959 dan 276) roda memiliki arti barang bundar (berlingkar dan biasanya berjeruji) sedangkan dua artinya bilangan yang dilambangkan dengan angka 2. Makna dari kata Roda Dua adalah roda yang memiliki jumlah dua, sedangkan maksud dari kalimat pada pamflet tersebut memberi informasi yang ditujukan kepada kendaraan yang berroda dua roda yaitu sepeda motor. Parkir merupakan keadaan tidak bergerak yang bersifat sementara karena ditinggalkan oleh pengemudinya. Jika yang pamflet tersebut memerintahkan aturan parkir kepada pengguna roda dua, penulisan yang benar adalah "PENGGUNA RODA DUA DILARANG MEMARKIRKAN DISINI'. Penulis menambah imbuhan $\mathrm{Me}+\ldots+k a n$ pada kata dasar Parkir menjadi Memarkirkan agar terbentuk suatu kegiatan melakukan.

\section{b. Penggunaan kata Disini atau Di sini}

Kata depan di pada kata disini berfungsi sebagai imbuhan dan bukan kata depan. $D i$ sebagai imbuhan yang jika diikuti oleh tempat atau penunjuk tempat, maka penulisannya dipisah. Jadi kata disini pada pamflet tersebut ditulis di sini. Penulisan kata disini yang tidak diberi jarak antara imbuhan $d i$ dan kata penunjuk tempat sini sering terlihat di berbagai pamflet dan tulisan lainnya. Hal ini dipengaruhi oleh pengucapan bahasa lisan yang tidak memperlihatkan jarak antara pengucapan $d i$ dengan kata penunjuk tempat sini, sehingga pengguna bahasa yang tidak mengetahui kaidah penulisan bahasa yang benar tidak menghiraukan bagaimana penulisan yang benar, sehingga penulisan kata disini dianggap sudah benar.

Setelah peneliti mengalisis, penulisan perbaikan pada pamflet tersebut yaitu:

PENGUMUMAN

PENGGUNA RODA DUA DILARANG

MEMARKIRKAN DISINI

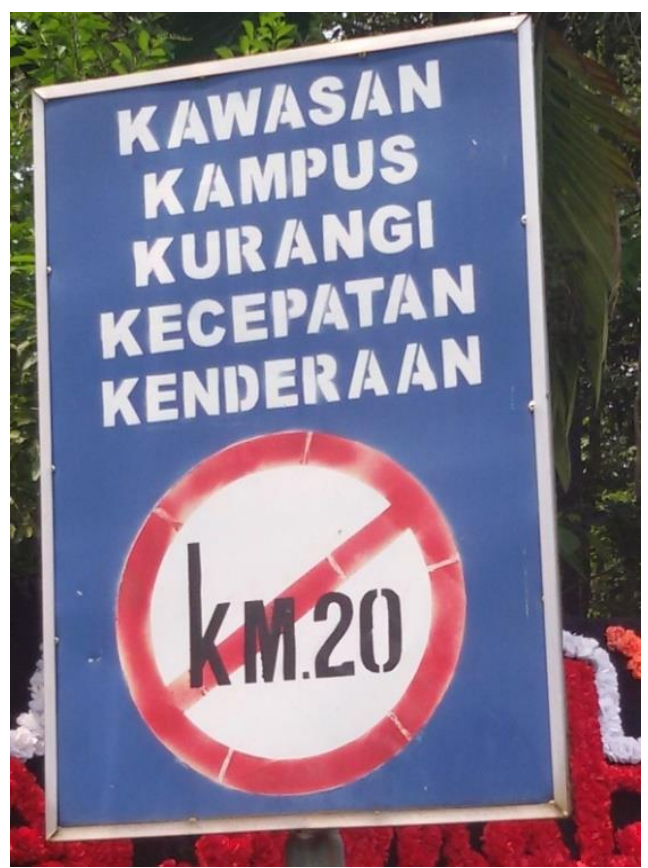

Gambar 3

Gambar 3 di ambil pada parkiran Universitas Medan Area tanggal 29 Agustus 2015. Pada pamflet tersebut 
ditemukan beberapa kesalahan yang akan dibahas, berikut ini pembahasannya.

\section{a. Penggunaan kata Kenderaan}

Kesalahan terletak penulisan kata Kenderaan (tidak baku) yang seharusnya dituliskan Kendaraan (Baku). Kesalahan yang sama ditemukan pada gambar pamflet nomor 1 karena pamflet tersebut diambil dilokasi yang sama yaitu Universitas Medan Area.

\section{b. Penggunaan simbol lalu lintas (Ø)}

Simbol yang berbentuk lingkaran dengan garis miring $(\varnothing)$ memiliki makna dilarang, seharusnya tidak digunakan pada pamflet tersebut, karena akan bermakna dilarang melaju pada kecepatan Km 20 yang artinya boleh melaju pada kecepatan 40 atau kecepatan tinggi diatas Km 20. Kesalahan juga terlihat pada penulisan Km.20. Berdasarkan aturan pada Ejaan yang Disempurnakan (2012:22) penulisan lambang satuan ukuran, takaran, timbangan dan mata uang tidak diikuti tanda titik. Kilometer dalam Kamus Besar Bahsa Indonesia (2007:569) merupakan satuan ukuran yang disingkat dengan $\mathrm{Km}$. Oleh karena itu, tidak dibenarkan menggunakan tanda baca titik di belakang huruf $m$. Jadi penulisan yang benar adalah Km 20.

Setelah peneliti mengalisis, penulisan perbaikan pada pamflet tersebut yaitu:

KAWASAN

KAMPUS
KURANGI KECEPATAN

KENDARAAN

$\mathrm{Km} 20$

\section{B. Analisis Penulisan Pada Papan Nama Pertokoan}

Peneliti mengambil tiga sampel papan nama pertokoan yang akan diteliti, berikut pembahasannya

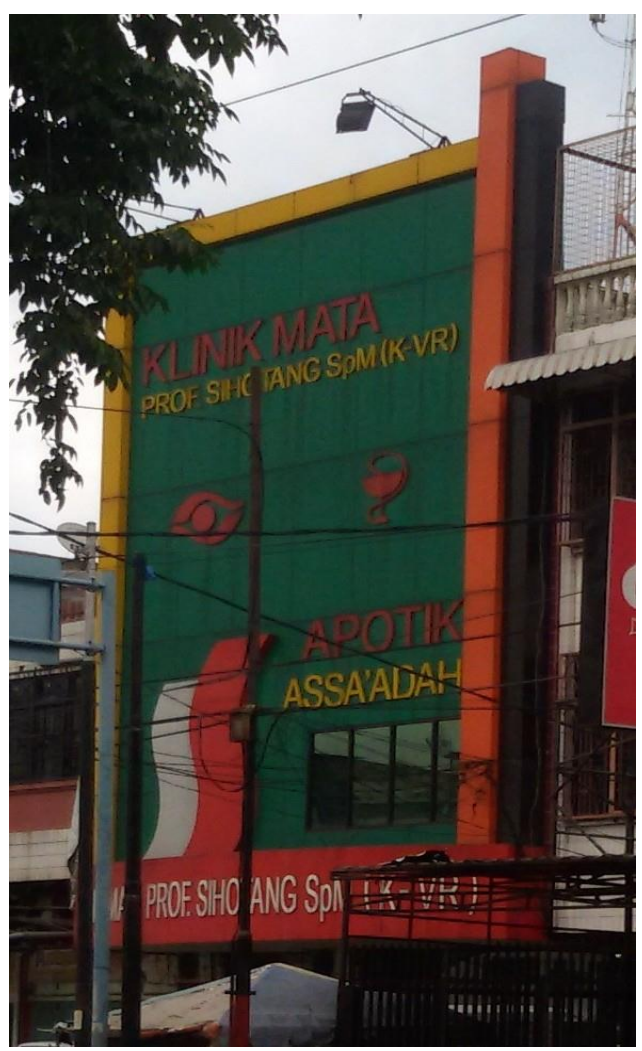

Gambar 4

Gambar 4 terdapat di jalan Gatot Subroto, kota Medan. diambil pada tanggal 28 Agustus 2015. Pada papan nama pertokoan tersebut jelas terlihat salah dalam penulisan kata Apotik, berikut penjelasannya:

Menurut Kamus Besar Bahasa Indonesia (2007:62), Apotek berarti toko tempat meramu dan menjual obat 
berdasarkan resep dokter serta memperdagangkan barang medis. Kata apotek sering disebut juga rumah obat. Jika kita jeli, kata apotik masih banyak ditulis di depan toko yang menjual obat ini. Beberapa pemilik toko dan karyawan tidak mengetahui jika kata "apotik" yang digunakan salah.

Kata apotek dan apotik diserap dari ejaan asing yaitu bahasa Belanda "apotheek" yang berarti tempat menjual dan kadang membuat atau meramu obat. Istilah "apotheek" ini berasal dari bahasa Yunani "apotheca" yang secara harfiah berarti "gudang" atau "penyimpanan". Dalam bahasa asalnya tersebut, dapat kita lihat bahwa gugus vokal yang digunakan pada suku kata ketiga kata "apotheek" adalah "ee", bukan "ie". Sesuai dengan kaidah atau ketentuan penyesuaian Ejaan Asing ke dalam bahasa Indonesia yang telah diatur dalam buku Pedoman Umum Ejaan Bahasa Indonesia yang Disempurnakan, huruf " $e e$ " diserap ke dalam bahasa Indonesia menjadi " $e$ ". Oleh karena itu, penulisan yang baku adalah Apotek, bukan Apotik. Selanjutnya, ahli dalam ilmu obat-obatan' disebut sebagai Apoteker. Penggunaan kata apotik dipengaruhi oleh anggapan masyarakat bahwa bahasa tersebut sudah baku karena sering dilafalkan demikian, sehingga masyarakat lupa bahwa kata apotik merupakan kata yang tidak baku. Selain itu, kata tersebut sering muncul pada media luar ruang lain yang juga dituliskan apotik, sehingga masyarakat pengguna bahasa kurang memerdulikan lagi kebakuan kata tersebut. Kesalahan tersebut sama halnya dengan kata nasihat yang sering dilafalkan dan ditulis dengan kata nasehat.

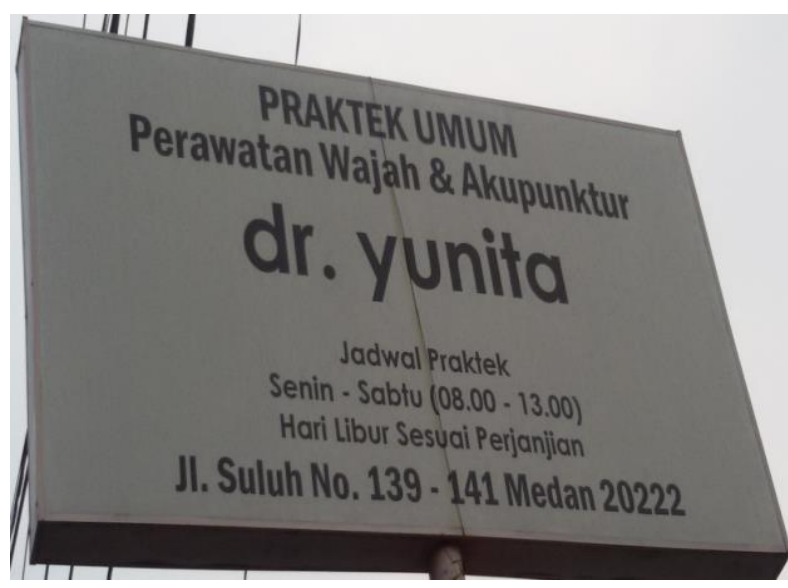

\section{Gambar 5}

Gambar 5 di atas yang terdapat di jalan Suluh, Kecamatan Medan Perjuangan. Diambil pada tanggal 29 Agustus 2015. Pada papan nama pertokoan tersebut jelas terlihat salah dalam penulisan kata Praktek, penggunaan huruf kapital, dan tanda baca pisah (-). Berikut penjelasannya.

\section{a. Penggunaan kata Praktek atau Praktik}

Penulisan yang benar adalah Praktik. Dalam Kamus Besar Bahasa Indonesia (2007: 892) 1. praktik adalah pelaksanaan secara nyata apa yang disebut dalam teori; 2. praktik adalah pelaksanaan pekerjaan (dokter, pengacara,dsb). Penyesuaian 
akhiran -ic dalam bahasa Inggris atau -ijk dalam bahasa Belanda menjadi $-i k$ dalam bahasa Indonesia. Praktik merupakan serapan yang tepat, sehingga kata yang tepat adalah kerja praktik, malpraktik, dan praktik dokter. Kata praktek pada papan nama pertokoan tersebut jelas tertulis berdasarkan pelafalan masyarakat dalam bahasa lisan. Penggunaan kata praktek dipengaruhi oleh anggapan masyarakat bahwa bahasa tersebut sudah baku karena sering dilafalkan demikian, sehingga masyarakat lupa bahwa kata praktek merupakan kata yang tidak baku. Selain itu, kata tersebut sering muncul pada media luar ruang lain yang juga dituliskan praktek, sehingga masyarakat pengguna bahasa kurang memerdulikan lagi kebakuan kata tersebut.

\section{b. Penggunaan Huruf Kapital}

Huruf kapital dipakai sebagai huruf pertama unsur-unsur nama orang, sedangkan singkatan kata dokter disingkat menjadi $d r$. sehingga penulisan yang tepat yang terdapat pada papan nama pertokoan di atas ialah dr. Yunita.

\section{c. Penggunaan Tanda Baca Pisah (-)}

Tanda baca pisah (-) dipakai di antara dua bilangan, tanggal atau tempat dengan arti 'sampai dengan' atau 'sampai ke'. Penulisan yang salah kerap terjadi dikalangan masyarakat dalam penulisan yaitu penggunaan tanda baca pisah (-) pada keterangan waktu yang menunjukkan 'sampai dengan', seperti pada gambar di atas tertulis Senin - Sabtu (08.00 - 13.00) dan no. 139 - 141. Penulisan yang seharusnya tidak memberikan jarak (spasi) pada kedua keterangan waktu tersebut sehingga menjadi Senin-Sabtu (08.0013.00) dan no. 139-141.

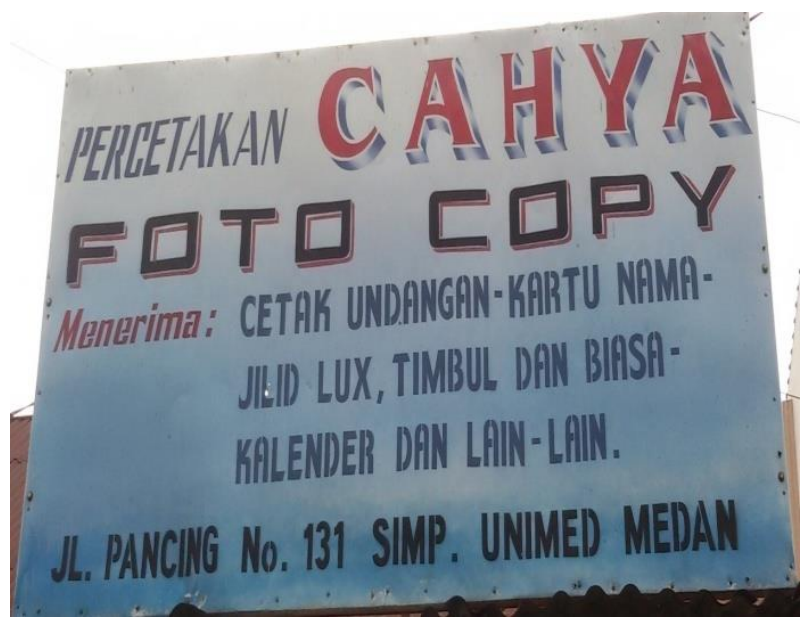

\section{Gambar 6}

Gambar 6 di atas yang terdapat di jalan Pancing, Diambil pada tanggal 30 Agustus 2015. Pada papan nama pertokoan tersebut jelas terlihat salah dalam penulisan kata Foto Copy, tanda baca titik dua (:), tanda baca pisah (-), penggunaan kata jilid lux dan singkatan kata Simp. Berikut penjelasannya.

\section{a. Penulisan Foto Copy atau Foto Kopi}

Penulisan yang tidak tepat adalah pada kata Copy yang berasal bahasa Inggris yang berarti salinan. Kata copy dalam bahasa Indonesia ditulis kopi, foto bermakna potret. Menurut kamus Besar Bahasa Indonesia (2007: 321) Foto kopi adalah hasil reproduksi (penggandaan) 
fotografis terhadap barang cetakan (tulisan). Jika penulis papan nama pertokoan ingin menggunakan bahasa Inggris, seharusnya kata foto juga ditulis dalam bahasa Inggris yaitu Photo sehingga menjadi Photo Copy.

\section{b. Penggunaan tanda baca titik dua (:)}

Penggunaan tanda baca titik dua (:) setelah kata menerima tidak dibenarkan menggunakan jarak atau spasi. Menurut Ejaan Yang Disempurnakan (2012:41) Tanda titik dua dipakai pada akhir suatu pernyataan lengkap yang diikuti rangkaian atau pemerian. Selain itu, sebelum tanda baca titik dua (:)

\section{c. Penggunaan Tanda Baca Pisah (-)}

Tanda baca pisah (-) dipakai di antara dua bilangan, tanggal atau tempat dengan arti 'sampai dengan' atau 'sampai ke'. Penggunaan tanda tersebut tidak dibenarkan menggunakan jarak atau spasi. Selain itu untuk menjelaskan 'kategori' yang diterima, seharusnya penulis papan nama tersebut mengurutkannya ke bagian bawah sejajar dengan kata menerima yang diikuti dengan kata cetakan. Menerima memiliki makna mendapat atau memperoleh sesuatu dan cetakan memiliki makna membentuk sebuah benda. Sehingga penulisan yang tepat yaitu:

MENERIMA CETAKAN:

UNDANGAN

KARTU NAMA

JILID LUX, TIMBUL DAN BIASA
KALENDER

DAN LAIN-LAIN

\section{d. Pengguaan kata Jilid Lux}

Menurut Kamus Besar Bahasa Indonesia (2007: 473) jilid berarti jahitan buku (majalah dsb), sedangkan lux merupakan penggalan kata luxury dari bahasa Inggris yang berarti kemehawan atau barang mewah. Penggunaan kata lux tidak tepat jika yang dimaksud adalah Jilid Sampul depan keras atau dalam bahasa Inggris disebut Hard Cover. Jilid hard cover merupakan jenis jilidan yang sampul depannya dibuat dari bahan kardus khusus, dan menjadikan sampul terkesan kaku dan tebal sehingga menjadi lebih awet. Ciri jilidan ini terdapat tali pita di dalam jilidan namun tidak semua ada. Umumnya kata Lux yang dimengerti oleh kalangan mahasiswa atau masyarakat lainnya pada saat melakukan penjilidan jenis tulisan skripsi, tesis dan disertasi. Sedangkan makna lux itu sendiri berbeda dengan hasil akhir tujuan yang dimaksud. Oleh karena itu penulisan yang tepat pada papan nama pertokoan tersebut adalah JILID Hard Cover dalam bahasa Inggris atau jilid Sampul Keras dalam bahasa Indonesia. Sesuai dengan kaidah penulisan bahasa asing kata tersebut dicetak miring.

\section{e. Singkatan kata Simp}

Aturan penyingkatan dan akronim tidak diberlakukan pada kata simp yang dimaksud adalah simpang. Arti kata 
Simpang dalam Kamus Besar Bahasa Inodesia (2007: 1067) adalah sesuatu yang memisah (membelok, bercabang, melencong dsb) dari yang lurus atau tempat berbelok. Penyingkata kata simp dipengaruhi oleh bahasa singkatan yang ada pada bahasa SMS (Short Message Service) yang merupakan pesan singkat berupa teks yang dikirim dan diterima antar sesama pengguna telepon genggam. Kriteria penulisan SMS terdapat banyak penggunakan bahasa yang tulisannya disingkat, seperti kata makan disingkat menjadi $m k n$, atau kata gang disingkat menjadi gg. Pada penulisan papan nama pertokoan hendaknya penulisan kata simp tidak disingkat. Oleh karena itu, penulisan yang benar adalah Simpang.

\section{Kondisi-Kondisi yang Berpotensi Menjadi Penyebab Kesalahan Penulisan Pamflet dan Papan Nama Pertokoan}

Dari hasil kajian yang telah dilaksanakan, terdapat kondisi-kondisi yang berpotensi menjadi penyebab tingginya tingkat kesalahan bahasa dalam penulisan pamflet dan papan nama pertokoan di wilayah Medan. Pertama, pamflet dan papan nama pertokoan merupakan media luar ruang yang ciricirinya ditampilkan untuk dapat dilihat, dibaca dan diketahui oleh masyarakat bahwa adanya informasi pada pamflet dan papan nama pertokoan tersebut, hal tersebut mengakibatkan masyarakat tidak menghiraukan lagi penulisan yang sesuai dengan kaidah bahasa Indonesia yang baik dan benar karena bahasa yang digunakan dalam penulisan pamflet dan papan nama pertokoan merupakan bahasa yang mudah dimengerti dan langsung dipahami dalam sekali dibaca. Kedua, bahasa yang digunakan pada penulisan pamflet dan papan nama pertokoan merupakan bahasa lisan yang sering diucapkan masyarakat sehingga ditemukan kesalah kaprahan dalam penulisannya. Ketiga, masyarakat lain yang mengetahui kesalahan pada penulisan pamflet dan papan nama pertokoan tidak pernah memprotes tentang adanya kesalahan baik dalam segi penulisan maupun kaidahnya, sehingga tidak ada upaya untuk memperbaiki kesalahan yang secara langsung terbiarkan bebas terpampang pada media luar ruang tersebut. Keempat, karena kesalahan tersebut dianggap tidak menjadi masalah yang serius sehingga kesalahan pada penulisan pamflet dan papan nama pertokoan sering dijumpai dibeberapa jalan di wilayah medan. Kelima, terdapat ketidakkonsistenan dalam penulisan bahasa Inggris yang disebabkan oleh bahasa umum yang digunakan masyarakat dalam pemilihan kata. 


\section{PENUTUP}

Berdasarkan data-data yang ditemukan di lapangan dan hasil analisis, dapat disimpulkan bahwa kesalahan berbahasa Indonesia pada penulisan pamflet dan papan nama pertokoan masih sering dijumpai yang belum/tidak sesuai dengan kaidah bahasa Indonesia yang baik dan benar. Pada umumnya pemakai bahasa dalam berbahasa cenderung menggunakan jalan pikirannya tanpa mempertimbangkan aturan-aturan yang ada dalam bahasa. Bentuk-bentuk kesalahan penulisan meliputi kesalahan penulisan tanda baca, kesalahan penulisan singkatan, kesalahan pemilihan kata, dan kesalahan penulisan ejaan dan makna yang disampaikan belum jelas. Kesalahan penulisan pada pamflet dan papan nama pertokoan diakibatkan oleh pengaruh penggunaan bahasa seharihari atau tulisan yang ditulis berdasarkan ucapan masyarakat. Selain itu, masyarakat juga kurang menghiraukan bagaimana penggunaan bahasa dalam tulisan yang benar, sehingga kesalahan tersebut sering dijumpai.

Fenomena ketidakmahiran berbahasa Indonesia menjadi sangat lazim dan mudah ditemukan. Hampir di setiap tampat umum terpampang tulisan-tulisan dalam sarana informasi umum yang tidak memperhatikan aspek kebakukan bahasa, selain itu penggunaan istilah asing juga sering dipakai. Kecenderungan menggunakan bahasa yang tidak logis dalam sarana informasi umum sangat besar pengaruhnya terhadap masyarakat. Penggunaan kata serapan dan pola kalimat asing juga diperhatikan. Banyak upaya yang dapat dilakukan mulai dari penanaman kebiasaan berbahasa Indonesia yang baik dan benar, hingga penyuluhan tentang penggunaannya.

Masalah Bahasa Indonesia bukan hanya masalah orang-orang yang berkecimpung dalam dunia bahasa Indonesia, tetapi merupakan masalah seluruh warga Negara Indonesia. Itulah sebabnya setiap warga Negara Indonesia harus memiliki sikap positif terhadap bahasa Indonesia. Sikap positif tersebut diwujudkan dengan melestarikan penggunaan bahasa Indonesia yang baik dan benar sesuai kaidah-kaidah pokok dan menerapkannya dalam kehidupan seharihari. Bahasa Indonesia harus dipahami dengan penuh kesadaran dan berbahasa Indonesia yang baik dan benar seharusnya ditanamkan sejak dini.

\section{DAFTAR PUSTAKA}

Alwi, Hasan dkk. Kamus Besar Bahasa Indonesia (Edisi Ketiga). Jakarta: Balai Pustaka.

Badudu. 1986. Inilah Bahasa Indonesia Yang Benar II. Jakarta: PT Gramedia. 
Chaer, Abdul. 20019. Pengantar Semantik Bahasa Indonesia. Jakarta: Rineka Cipta.

Chaer, Abdul dan Leone Agustina. 2010. Sosiolinguistik Perkenalan Awal. Jakarta: Rineka Cipta.

Mahsun. 2005. Metode Penelitian Bahasa: Tahapan Stategi, Metode, dan Tekniknya. Jakarta: PT Raja Grafindo Persada.

Nien \& Gunawan. 2012. Aturan terbaru EYD. Jakarta: Cakrawala.

Poerwadarminta. 2003. Kamus Umum Bahasa Indonesia (Edisi ketiga). Jakarta: Balai Pustaka

Tarigan, H.G. 2011. Pengajaran Analisis Kesalahan Berbahasa. Bandung: Angkasa.

Tim Lima Adi Sekawan. 2012. EYD Plus.

Jakarta: Lima Adi Sekawan 